\title{
男子大学生の飭酒行動 一遗后素因と社会・少理的要因の関連一
}

○林宏美, (京都大学医学部付属病院), 祖父江育子（京都大 学医療技術短期大学部)，竹下達也, 森本兼暈（大阪大学医 学部環境医学教室), 向井千鶴（京都大学医学部附属病院）

目的：アルコール依存, 高血圧などのアルコール関連疾患を発症する要因として アルデヒド脱水素酔素（ALDH2）の関与が指摘されている．そこでアルコール関連問 題に至る経路を解析する研究の一部として, 遺伝素因と社会・心理的要因の関連を 明らかにする目的で, ALDH2の表現型と飲酒行動の関連について調査した.

方法：対象は $\mathrm{K}$ 大学体育系クラブに所属する男子大学生102名であった. ALDH2の 表現型のスクリーニングとして，パッチテストをMuramatsu(1989)の方法に準拠して 実施した。飲酒量, 飲酒頻度, 社会的飲酒行動は, 自宅や友人との飲酒機会, クラ ブのコンパにおける飲酒機会で調査し, 問題飲酒行動は青山(1984)が作成した18項 目を一部改変して用いた。

飲酒量はすべて純エタノール量に換算し, 分析にはWilcoxon 2-sample test, Chi-square test, Fisher exact testを用いた。

結果：パッチテスト陰性者（Non-flusher）は71名, 陽性者（Flusher）は31名で あった. 表 1 に示すように, Non-flusherの飲酒開始年齢はFlusherよりも有意には やく，問題飲酒行動数も有意に多数であった。自宅や友人との飲酒機会における飲 酒量も, Flusherより多量の傾向を示した。またNon-flusherはクラブのコンパにお いて，自主的に飲酒を開始する者，フラッシング反応が生じている飲酒者に飲酒の 無理強いをする者の頻度が, F1usherよりも有意に高值であったＡLDH2の表現型と 社会・心理的要因の関連を明らかにするため, 自宅や友人との飲酒機会における飲 酒開始時の社会的飲酒行動に着目し各飲酒行動について解析した.

表 2 に示すように，自主的に飲酒を開始するNon-flusherの 2 機会の飲酒量，自宅 やコンパにおける飲酒頻度, 問題飲酒行動数は, 他者のすすめによって飲酒を開始 するNon-flusherよりも有意に高值であった。しかしFlusherは飲酒開始時の社会的 飲酒行動による差異を示さなかった。

表 3 に示すように，自主的に飲酒を開始するNon-flusherは，他者のすすめで飲酒 を開始するNon-flusherよりも，他者のすすめを断れない者，フラッシングを示して いる飲酒者に飲酒の無理強いをする者が有意に高頻度であったＦlusherは 2 機会に おける飲酒開始時の行動にのみ有意な関連が認められた。

考察および結論：Non-flusherはFlusherよりも飲酒量, 問題飲酒行動が高值であ り, 積極的で不適切な社会的飲酒行動を示したことから, ALDH2の関与が示唆された. また自主的に飲酒を開始するNon-flusherは他者のすすめで飲酒を開始する Non-flusherよりも, 飲酒量, 飲酒頻度, 問題飲酒行動と積極的で不適切な社会的飲 酒行動が有意に高值であったことから，社会・心理的要因の関与が示唆された. 
表 1 Non-flusherとFlusherの飲酒行動比較

\begin{tabular}{lrrr}
\hline 飲 酒 行 動 & $\begin{array}{c}\text { Non-flusher } \\
\mathrm{n}=71 \\
\text { Mean } \pm \text { SD }\end{array}$ & $\begin{array}{c}\text { Flusher } \\
\mathrm{n}=31 \\
\text { Mean } \pm \mathrm{SD}\end{array}$ & \\
\hline 飲酒開始年齢 & $16.2 \pm 2.8$ & $17.5 \pm 1.4$ & $* *$ \\
飲酒量 (自宅や友人との飲酒) & $68.8 \pm 88.7$ & $39.1 \pm 53.2$ & + \\
飲酒量 (クラブのコンパ) & $113.2 \pm 93.5$ & $98.6 \pm 69.1$ & \\
問題飲酒行動数 & $4.5 \pm 2.7$ & $3.0 \pm 2.0$ & $* *$ \\
\hline
\end{tabular}

飲酒量 $(\mathrm{ml})$ : 純エ夕ノール量に換算

$+\mathrm{P}<0.10 \quad * * \mathrm{P}<0.01 \quad$ Wilcoxon 2-Sample Test

表 2 自宅や友人との飲酒機会における飲酒開始時の行動による飲酒行動比較

\begin{tabular}{|c|c|c|c|c|c|}
\hline \multirow{2}{*}{ 飲 酒 行 動 } & \multicolumn{2}{|c|}{ Non-flusher } & & \multicolumn{2}{|c|}{ Flusher } \\
\hline & 自主的 & $\begin{array}{c}\text { 他者のすすめ } \\
n=14\end{array}$ & & $\begin{array}{l}\text { 自主的 } \\
n=20\end{array}$ & $\begin{array}{c}\text { 他者のすすめ } \\
n=11\end{array}$ \\
\hline 飲酒量（自宅や友人との飲酒） & $77.7 \pm 98.1$ & $40.9 \pm 78.6$ & $*$ & $46.1 \pm 63.2$ & $26.3 \pm 25.1$ \\
\hline 飲酒量 (クラブのコンパ) & $124.0 \pm 94.9$ & $69.0 \pm 73.9$ & $*$ & $110.1 \pm 73.0$ & $77.7 \pm 58.8$ \\
\hline 問題飲酒行動数 & $5.1 \pm 2.5$ & $2.3 \pm 2.5$ & $* * *$ & $3.2 \pm 2.2$ & $2.6 \pm 1.8$ \\
\hline
\end{tabular}

飲酒量 $(\mathrm{ml})$ : 純エ夕ノール量に換算

* $\mathrm{P} 0.05 \quad$ *** $\mathrm{P}<0.001 \quad$ Wilcoxon 2-Sample Test

表 3 自宅や友人との飲酒機会における飲酒開始時の行動と社会的飲酒行動の関連

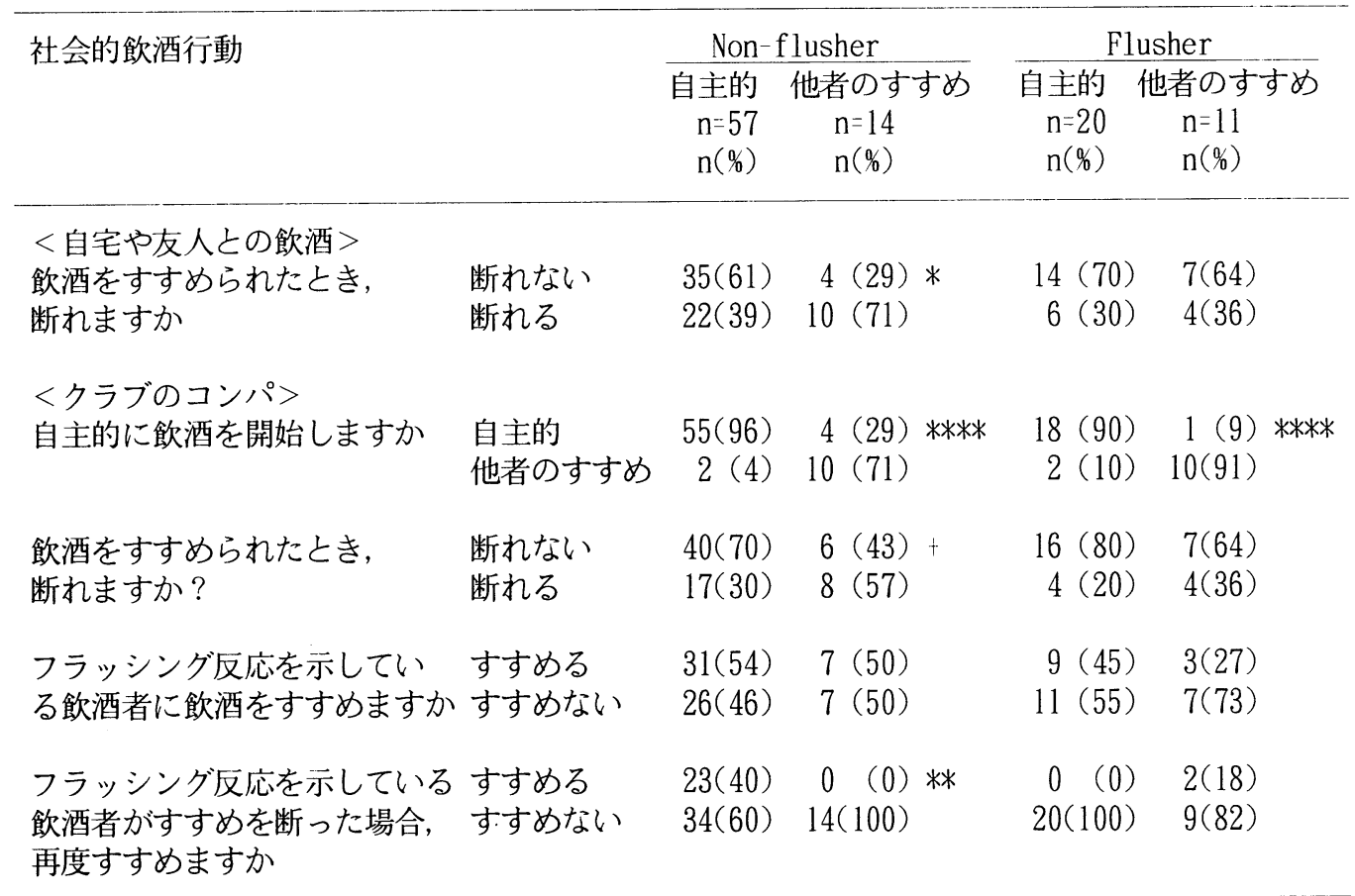

$+\mathrm{P} 0.10$ * $\mathrm{P}<0.05$ ** $\mathrm{P}<0.01$ **** $\mathrm{P}<0.0001$ Chi-square TestあるいはFisher Exact Test 